\title{
Violence against Women and Femicide: an analysis on the murders of foreign women in Italy
}

\author{
Alessandra Dino ${ }^{1}$ \\ Accepted: 21 January 2022 / Published online: 11 February 2022 \\ (c) The Author(s) 2022
}

\begin{abstract}
This paper presents the results of a research on the representations of femicide in the judicial field, in Italy. The use of the term femicide is analysed through the lens of the normative process, examining its social meanings and questioning its political and economic anchoring using the "juridical field" model (Bourdieu 1986). The essay is based on a wide theoretical framework. It starts by highlighting the problems evoked by the term 'femicide' (Corradi, et al. 2016; Radford and Russell 1992); its declension in criminal law and jurisprudence through its coding in specific types of offence (Merli 2015). The topics of power and imbalance between the sexes (Goffman 1977) are analysed by presenting their juridical definitions and those found in penal codes (Casanova 2016; Cavina 2011; Feci and Schettini 2017). This perspective helps framing considerations about the results of the empirical research based on quantitative data taken from 93 verdicts of 'femicide' sentences which involved foreign or migrant victims (chosen from a corpus of 370 issued in Italy between 2010 and 2016) and qualitative aspects: gathered through expert interviews and the tales of violence against women in a verdicts' judgemental sample of murders of foreign women. The study confirms the way in which narrations produced in the "judicial field" - despite the "distortions" affecting them (Dubé 2012; Gusfield 1968) - prove to be rich sources for the knowledge of a phenomenon which, still today, suffers from a structural lack of data.
\end{abstract}

\section{A complex field of analysis: definitions, theories and methods}

One could affirm that truth is only one among the conditions through which the judicial judgment is successful in the pursuit of its aim or in the attainment of its goal. However, this aim or this target totally considered is not that of an

Alessandra Dino

alessandra.dino@unipa.it

1 Sociology of Deviance, Department "Cultures and Societies", University of Studies of Palermo, Viale delle Scienze edificio 15 -90128, Palermo, Italy 
achievement of the truth, but specifically the application of law (Viola 1995, 258-259).

These brief reflections summarise the first results of an academic research on the social representations of 'femicide' in juridical contexts, concentrating on the forms it takes and on narrations of extreme violence committed on foreign women in Italy (Dino 2021).

This study is part of a broader project brings together five Italian universities (Bologna, Padua, Turin, Salento and Palermo) (Lalli 2020). The Palermo research unit $^{1}$ was entrusted with analysing narrations of femicide in juridical discourse, to observe the structures of meaning used to represent extreme violence against women in the «juridical field» (Bourdieu 1986). ${ }^{2}$

The study's theoretical frame analyses the use of the term 'femicide' through the lens of normative processes, by examining its social representations (Di Nicola 2018; Farr and Moscovici 1984; Tringali 2019) and questioning both its political and economic anchoring (Arfini, et al. 2019; Pitch 1998, 2008). It also explores the issues connected to the use of the term 'femicide' in the frame of criminal law and jurisprudence due to the fact that it emerges in various types of offence (Bernardini and Giolo, 2017; Merli, 2015; Pitch, 1998; Pocar \& Ronfani, 2008; Scarponi, 2014; Virgilio 2010). The essay therefore considers the topic of "criminal law pervasiveness", which takes on the role of "stabilising common normative expectations" (Prina, in Ghezzi et al. 2017) with the risk of slipping into forms of "penal populism", especially in cases arising a serious social alarm (Anastasia et al. 2015).

The different uses of the term femicide within the "juridical discourse" and the "juridical field" is a complex and delicate task.

It is hard to trace the boundaries of the word femicide when used in the common language, as well as in literature and in specialist fields: from the media to international conventions, from political movements to public policies, all the way to the expert knowledge that has been dealing with the task from various angles (Cavender et al, 1999; Ghigi \& Rottenberg, 2019; Giomi and Magaraggia 2017). ${ }^{3}$ Even more complex is navigating the "juridical field", also because the examined phenomenon refers to a crime (the murder of a woman inasmuch as woman) that is not accurately

\footnotetext{
1 I would like to thank the research group: the collection of data is the result of a coordinated work and my reflections have been enriched by continuous exchanges with my colleagues.

2 As Bourdieu says (1986, p. 4): «The juridical field is the site of a competition for monopoly of the right to determine the law. Within this field there occurs a confrontation among actors possessing a technical competence [...] which consists essentially in the socially recognised capacity to interpret a corpus of texts sanctifying a correct or legitimised vision of the social world». Referring to the habitus Bourdieu specifies that it incorporates and reproduces the principles of vision and division constitutive of a social field, according to structured and structuring relationships with the environment, with respect to specific situations or classes of social conditions.

3 We are dealing with a peculiar form of violence: it is directed against the woman specifically because she is woman (Radford and Russell 1992), in different types of relationships and throughout different means of expression (physical, psychological, economic, political, institutional), both in the private and the public sphere (Ghigi and Sassatelli 2018).
} 
dealt with (and hardly ever will be) in a specific article of the Italian criminal code (the same is true for European legislation). ${ }^{4}$

The matter is complex also because, the specificity of these murders notwithstanding, the Italian Constitution, which, in article 3, stipulates the equality of all citizens in front of the law, prevents from applying, in case the victim is a woman, any different treatments other than aggravating circumstances in specific cases envisaged by the law and unless either she (just as anyone) finds herself in particular situations (e.g. is a minor or especially vulnerable), or the murder is committed with distinctive cruelty, premeditated and preceded by mistreating, accompanied by sexual abuse etc. (Fiandaca, 2020).

Bearing in mind these sensitive issues, in this essay we examine the numbers, the characteristics and the multiple meanings of different forms of violence against migrant and foreign women in Italy, using the normative process as a "mirror" for a reality that this process itself partially constructs (Baratta 1982; Bassano, 2017; Ferrari 2006; Pennisi 1991, 1998; Raiteri 1990). In particular our considerations regard the outcomes of the qualitative-quantitative investigation carried out over a corpus of 93 sentences of 'femicide' involving foreign or migrant victims (chosen from a corpus of 370 issued in Italy between 2010 and 2016), and 30 interviews with key informants. ${ }^{5}$ Some questions guided our study: How is violence narrated in trials? Which factors orient judges in defining their sentences? Are judicial narrations different when the victim is a foreigner?

The outcome of our empirical research, conducted through both qualitative and quantitative methods, led us, in this perspective, to a series of reflections (Cardano 2011; Gobo 2015; Weil 2017).

\section{Normative aspects and corporeity}

Minute, widespread, systemic and structural, violence against women is difficult to bring into focus on account of its motivations, which appear to be contradictory, trivial and convoluted (Karadole 2012; Corradi 2016; Pateman 1988; Pitch 2008). In particular, while reading the sentences one realises that it is often difficult for judges to pinpoint a precise motive (while in some cases they openly state that it was impossible to identify the motive, in others they mention "futile motives", and in still others they refer to a range of factors that may have contributed to the woman's murder). The report about femicide in Italy, drafted by the Ministry of Justice's Statistics Department also specifies that: «It was not possible to provide precise

\footnotetext{
${ }^{4}$ A codification of femicide as a crime has been reached in the legislations of several South American countries (such as Chile, Mexico and Guatemala) that have defined conditions and circumstances in order to frame the specific criminal offence, highlighting - case by case - the intimate dimension of the relationship, the misogyny, the relationship of domination/ownership, etc. (Merli, 2015, pp. 36-37; Spinelli, 2008, pp. 38-42).

5 These are: 9 magistrates, 7 members of the police, 2 lawyers, 6 representatives of associations against violence, 3 doctors, 2 psychologists and a psychiatrist, with specific experience of gender violence and working in different regions of Italy.
} 
statistics as to the motives, because in many cases they are "convoluted" and resist classification» (Bartolomeo 2017). ${ }^{6}$

What becomes immediately clear is that we are dealing with an exaggerated form of violence, pre-eminently committed on female bodies. For instance, the process of inferiorisation of foreign female bodies in the world of prostitution is based on the hierarchic scale of the "colour line" (Anderson and O'Connell Davidson 2003). This form of violence uses the most subtle forms of the micro-physics of power and the most insidious strategies of symbolic domination (Bourdieu, 1994, 1998; Foucault 1977; Grzyb 2016). Furthermore, it is interestingly uniform in some aspects of its content (the persistence of abuse over time) even while its meanings vary in different locations, historical periods and cultures (Feci and Schettini 2017; Re et al. 2019). ${ }^{7}$

This is a violence that emerges through forms of tenacity and brutality inflicted on the bodies of its victims, who are not only killed but massacred (even after their death), concentrating on specific symbolic areas, first and foremost the face and the arms.

This is a violence fuelled by both deep-rooted gender inequality and the ways it has been defined in jurisprudence and penal codes (Casanova 2016; Cavina 2011; Simone and Boiano 2018). ${ }^{8}$

Only in 2009 a law was approved in Italy that punishes the crimes of stalking and abuse (law no. 38, 23 April 2009). On 15 October 2013 a law (no. 242) was passed that introduces a few preventive and disciplinary measures, to fight all forms of gender violence (Pavich 2013; Recchione 2013). On 19 July 2019 was approved the law n. 69, journalistically known as "Red-Code", which includes new dispositions to protect victims of domestic and gender violence.

Complex theoretical questions are thus unfolded: from the topic of "sexed law" and "penal law of the difference" (Casadei 2016; Ferrajoli 1993, 2015; Pazè 2013; Pezzini 2012; Pitch 1998); to the concept of vulnerability, up to the critical theory of the law (Fineman 2008; Giolo and Pastore 2018; Giolo 2015; MacKinnon 2006). ${ }^{9}$

Stimulated by the social alarm awakened by the media the contradictions between penal law on paper and penal law "in action" get highlighted; ${ }^{10}$ while the pressing requests to take charge of the problem underline the "contaminations" between the level of the scientific research (historical, sociological, criminological, economical,

\footnotetext{
6 The difficulty arises from the complexity of the phenomenon to explain which, the various actors in the process use different forms of "justification", some of which appear to the judges disproportionate and inconsistent with the extent of the criminal act.

7 See also: Arendt 1970; Chesnais 1981; Ferrarotti 1979; Foucault 1994; Héritier 1996; Popitz 1986; Sofsky 1996.

${ }^{8}$ For quite some time, gender inequality was indeed ratified by laws and endorsed by judges; even recently, this still occurs through a "traditionalist and misogynist" reading of the Italian civil and penal codes (Pocar and Ronfani 2006, p. 38).

9 On the concept of vulnerability, cfr. vol. 5, n. 3, 2016 of «Gênero \& Direito».

10 See: Bullock 2007; Cavender, Bond-Maupin and Jurik 1999; Gius and Lalli 2014; Giomi 2015; Lamb and Keon 1995; Gregoratto 2017.
} 
psychological etc.), the one of public debate and the juridical/judicial one (Balloni $e t$ al. 2004; Agodi et al. 2001).

In a landscape characterised by reciprocal contaminations, the level of attention payed by mass media and the public opinion is channelled towards the judiciary system, in terms of expectations for reassurance in the face of social alarm, for the planning of intervention and prevention politics, and for the knowledge of the phenomenon (its phenomenology and motivations) (Dubé 2012; Gusfield 1968). ${ }^{11}$

\section{Violence against women: some data}

Statistical data on femicide is scarce, uneven and difficult to compare. A systematic collection has only been attempted in Italy since 2013; various criteria have been adopted in selecting and classifying these crimes, and this too makes it difficult to compare, especially since different normative systems coexist. No agreement has even been reached on the definition of femicide, some of whose most pertinent features include: women specifically killed by their partner or a person known to them; considering violence as a factor deeply rooted in the relation (Dugan et al. 2003); violence committed on a woman specifically as woman (Radford and Russell 1992) due to an asymmetrical structure in terms of power relations (Corradi et al. 2016; Spinelli 2008). (This last criterion is, among those proposed, the most difficult to apply, as it is, to a considerable variability in interpretation).

Murder is a male phenomenon (it predominantly involves men as both victims and perpetrators). In 2012-2013, in Italy, out of 505 wilful murders, $96 \%$ were committed by men and $4 \%$ by women; among the victims, $70 \%$ were men and $30 \%$ women. 1,036 women were killed in Italy from 2005 to 2013, coming to an average of 1 woman every three days; over $60 \%$ were killed by their partners, and $72 \%$ were Italian; $75 \%$ of the murderers were Italian (www.istat.it). According to a report published by Polizia Moderna in March 2018, over the last ten years the number of women killed (per year) appears to have fallen by 20\% (from 150 to 121) (Direzione Centrale Anticrimine 2018).

In 2020, there were, in Italy, 112 female victims of voluntary homicide. ${ }^{12}$ Since 2007, however, the amount of women among overall victims has increased by 10 percentage points, going from $24 \%$ to $34 \%$. Italy, according to the UNDOC, shows the lowest fall in this crime, which only dropped from 0.6 to 0.5 per 100 thousand inhabitants from 2002 to 2016 (Casa delle donne di Bologna 2017).

Therefore, the peculiar feature of murders of women is not their overall amount, in absolute terms, but their stability over time. This means that the sharp decrease in the amount of murdered men from 1992 to 2017 (which in Italy went from 4 per 100,000 to 0.72 ) is flanked by only a slight reduction in the amount of murdered

\footnotetext{
11 See, among others, the monographic volumes of Current Sociology (2016) and of Rassegna Italiana di Sociologia (2019).

12 https://www.eures.it/omicidi-in-calo-e-ai-minimi-storici-ma-non-diminuiscono-le-donne-uccise (visited on 7 October 2021).
} 
women (which went from 0.6 to 0.4 per 100,000 women). The male/female ratio in murder victims came to five men to one woman at the beginning of the period in question, and little less than two men to one woman $(1,6)$ at the end (Commissione Parlamentare 2017; Istat 2007, 2018).

Another fact that sets murdered women apart from men is the relation between the victim and the killer. While men are prevalently murdered by persons unknown to them or who remain unidentified (this percentage came to $\mathbf{6 4 . 2 \%}$ in 2019 in Italy), with women no less than $\mathbf{8 3 . 8 \%}$ are murdered by their partners, ex-partners or other relatives (this figure comes to $\mathbf{8 8 . 3} \%$ if one includes acquaintances). ${ }^{13}$

Moving from this general data to cases involving foreign women, according to the latest information provided by Istat, pertaining to 2019 , murder victims were foreigners in $\mathbf{1 9 . 7 \%}$ of all cases (17.6\% among men and $\mathbf{2 3 . 4 \%}$ among women). Thus, more than two out of ten women killed were native foreigners. ${ }^{14}$

The numbers of violent acts against women in Italy show that we are witnessing a widespread and steadily increasing phenomenon, which strikes against subjects of all ages, coming from any social class; acts of extreme violence are often more recurring in the intimate and familial sphere (Eures 2019a, 2019b; Istat 2007, 2015).

The research underlines the specificity of gender based violence and femicide, which do not present in Italy a generalised quantitative increase: while the charges for stalking, mistreating and violence have increased, recent data is signalling a decreasing trend for femicide $(-28.2 \%)$ and an increasing trend in the percentage of femicide inside the couple $(+5,4 \%)$ (Eures 2019a). As I said, the seriousness of the phenomenon is linked to its specificities, to its permanence in time, to the kind of victims, to the type of aggressors, to the transversality and pluralism of its manifestations.

The intimate partner violence is the only area in which female victims clearly outnumber male ones, overturning stereotypes and prejudices and overcoming cultural and geographical barriers, to replicate everywhere the same power dynamics.

\section{The research: methodological aspects}

Before going to the heart of the issue and presenting our first results, I would like to briefly provide a few indications on our research questions sources and tools, along with the theoretical and methodological framework that guided us. I will begin with the main questions that - as I said before - acted as our starting point: How violence is narrated in trials? Which factors orient judges in defining their sentences? Are judicial narrations different when the victim is a foreigner?

Given that there are no precedents for our research in literature, it has an exploratory nature. Specific tools had to be defined, working on three different levels of detail according to a quali-quantitative approach (Cresswell 2014). The quantitative

13 https://www.istat.it/it/violenza-sulle-donne/il-fenomeno/omicidi-di-donne (visited on 7 October 2021).

14 Ibidem. 
analysis was carried out on a collection of sentences on cases of femicide, most of which went to trial between 2010 and 2016, which we obtained from the Statistics and Organisational Analysis Department of the Italian Ministry of Justice.

We examined 467 sentences which involved episodes of 'femicide', with a total of 370 final sentences covering all cases. Two things must be specified: the first concerns the criteria used in selecting the sentences and the second involves the difference between the number of cases and the number of sentences.

The aim of our analysis led us to examine all the cases of the deliberate murdering of women that can be considered as femicide: this led us to include as cases of femicide all situations in which women were specifically killed by their partner or a person known to them and violence was a factor deeply rooted in the relationiship; the murder took place within a scenario of domination and gender violence with an asymmetrical structure in terms of power relations. ${ }^{15}$ Therefore, while we excluded cases in which the victim was a woman but this was only due to circumstance (e.g. a bank robbery that ended with a homicide), we included as 'femicides' cases in which the use of power and evidence of violence appear in more unusual forms (e.g. cases in which a woman is brought to commit suicide through violent coercion (Dino 2012), or murders of women by strangers that show forms of "gender violence" which appear in the definitions provided by international conventions) (Agliastro 2014; Battarino 2013).

The difference between the number of cases and the number of sentences is due to the fact that for one and the same case (which may include more than one victim), at times we encountered sentences that were appealed. In such instances, we chose the most recent sentence (whose opinion includes considerable references to the previous ones). ${ }^{16}$

As for the part regarding quantitative data, the project team used 370 femicide sentences issued in Italy between 2010 and 2016, but - as already mentioned - in this essay we have analysed, in particular, the 93 cases involving foreign or migrant victims.

To collect and classify this information, a database was prepared. It was designed so as to detect the variables required by the aims of our study, and the data thus ranges from a general identification of the sentences to the ways in which the crime was committed, including locations and timing, along with profiles of the victim and the killer, as well as the social figures present in the trial (whether professionally qualified or not: coroners, psychologists, psychiatrists, experts, members of law enforcement, family members, acquaintances, uninvolved witnesses), and probative materials supporting the sentence (Corradi, Stockl 2014; Corradi, Piacenti 2016; Dawson 2016; Iezzi 2010).

The qualitative data was collected by interviewing key informants who, by way of their professional role, have been involved in cases of femicides. Our goal was to take note of the definitions of extreme gender violence formulated by "experts"

\footnotetext{
15 Due to its "operative" characteristics, the femicide category recalls the notion of "sensitising concept" by Blumer (1969) that more than indicating what to see suggests the directions along which to look.

16 Our sample consists of 100 sentences of First degree and 270 of Second degree.
} 
and the frames within which public opinion is made aware of judiciary discourse on femicide. Between February 2017 and July 2018, 30 key informants were interviewed, chosen among those having "expert knowledge" and experience in cases of gender violence, including judges, members of law enforcement, coroners, courthouse experts, lawyers and the staff of anti-violence centres.

Our work also included analyses of the narrations of violence against women in selected sentences (Bruner 2002; Di Donato 2008). This was aimed at understanding the factors that come into play when a judge is called on to give a sentence; how influential "expert knowledge" is in judicial narrations of femicide; which features are present in the statements made by social figures; and what they are based on (Ferrer Beltrán, 2004, 2007; Canzio 2001; Fiandaca 2005; Tuzet 2013).

Frequent are, in fact, the contaminations of forms, contents, anchorings and meanings, which the magistrates use to express their judgement, through the verdict, the result of hybrid languages inside the spoken language and inside the logic of the law (Bellucci 2005; Jackson 1985, 1998; Jacquemet, 1996; Landowski 1988; Mortara Garavelli 2001). ${ }^{17}$

\section{The research: quantitative data on femicides involving foreign women}

This is the scenario of gender violence and violence as a means of domination that forms the backdrop for our analysis of quantitative data on femicides concerning foreign women in Italy, taken from our corpus of 370 sentences, covering all cases.

Analysing the tables, as to the distribution of victims and perpetrators according to nationality, we immediately find that while the (official) amount of foreigners accounts for roughly $8.5 \%$ of the Italian population, ${ }^{18}$ both foreign murderers $\mathbf{2 5 \%})$ and all victims (25\%) are over-represented. The percentage of foreign women killed is therefore very high, even compared to Italian women, who remain the most numerous victims in absolute terms. Among foreign women killed, the most numerous come from Eastern Europe (56\%) followed by South Americans (15\%). ${ }^{19}$ (Tables 1 and 2)

Considering the distribution of killers by age, we notice that Italian femicide perpetrators are mainly adults, concentrated between thirty and fifty years of age (49\%) but that, more generally, also appears in other age brackets. Among foreigners,

\footnotetext{
17 For the analysis of the judges' verdicts' argumentations, the four veridictive regimes by Landwoski prove to be illuminating (1988). On the topic, see Bassano's reflections (2017). See also: Latour (2002) and Matoesian (2001).

18 https://www.tuttitalia.it/statistiche/cittadini-stranieri-2021/ (visited on 7 October 2021).

19 It is perhaps useful to recall, without wishing to establish any direct correlation between this information, that, according to the latest available data on foreigners in Italy, women from Eastern Europe account for about $46 \%$ of the total number of foreign women, followed by Africans (about 22\%), Asian women (21\%) and women from Central and South America (7.6\%) (https://www.tuttitalia.it/statistiche/ cittadini-stranieri-2019/) (visited on 7 October 2021).
} 
Table 1 Perpetrator's nationality

\begin{tabular}{|c|c|c|c|}
\hline & Absolute values & Percentages & \\
\hline Italian & 278 & 75 & \\
\hline Foreign & 92 & 25 & \\
\hline Eastern Europe & 44 & & 48 \\
\hline $\begin{array}{l}\text { Middle and Southern } \\
\text { America }\end{array}$ & 9 & & 10 \\
\hline Africa & 23 & & 25.00 \\
\hline Asia & 12 & & 13 \\
\hline Other & 4 & & 4 \\
\hline Total & 370 & 100 & \\
\hline
\end{tabular}

Table 2 Victim's nationality

\begin{tabular}{lllll}
\hline & Absolute values & \multicolumn{2}{l}{ Percentages } \\
\hline Italian & 265 & & 72 & \\
Foreign & 93 & & $\mathbf{2 5}$ & \\
Eastern Europe & & 52 & & $\mathbf{5 6}$ \\
$\begin{array}{l}\text { Middle and Southern } \\
\quad \text { America }\end{array}$ & 14 & & $\mathbf{1 5}$ \\
Africa & & 11 & & 12 \\
Asia & & 12 & & 13 \\
Other & & 4 & & 4 \\
Unspecified & 12 & & 3 & \\
Total & 370 & & 100 & \\
\hline
\end{tabular}

instead, the age bracket responsible for the most murders is between eighteen and thirty, which accounts for $\mathbf{3 4 \%}$ of cases. Adding murderers between 31 and 40, the amount reaches $62 \%$. Foreigners who kill women are thus younger than Italians who do so (Table 3).

Considering the distribution of victims by age and nationality, our most significant point concerns, instead, the incredible absence of data. Indeed, in $63 \%$ of the cases, in the sentences we analysed, the age of the victim is not indicated (a sign of the low amount of interest shown during the trial towards the woman killed). If we were to base our conclusions on the data that is available (very partial, as mentioned) we would say that foreign victims are much younger than Italians (Fig. 1).

Comparing the data concerning the perpetrator's nationality and the victim's, other interesting facts emerge. Among foreigners, Asian men are the ones who mainly kill women with the same nationality: 83\% of perpetrators from Asia killed Asian women. With other groups of foreign killers, this same endogenous nature in the choice of victim does not appear. Men from Eastern Europe killed an Eastern European woman in $\mathbf{6 7 \%}$ of the cases, and African men kill Italian women in more than one instance out of two (59\%). This is interesting data, on which we must reflect upon and deepen our research (Table 4). 
Table 3 Age and nationality of the perpetrator

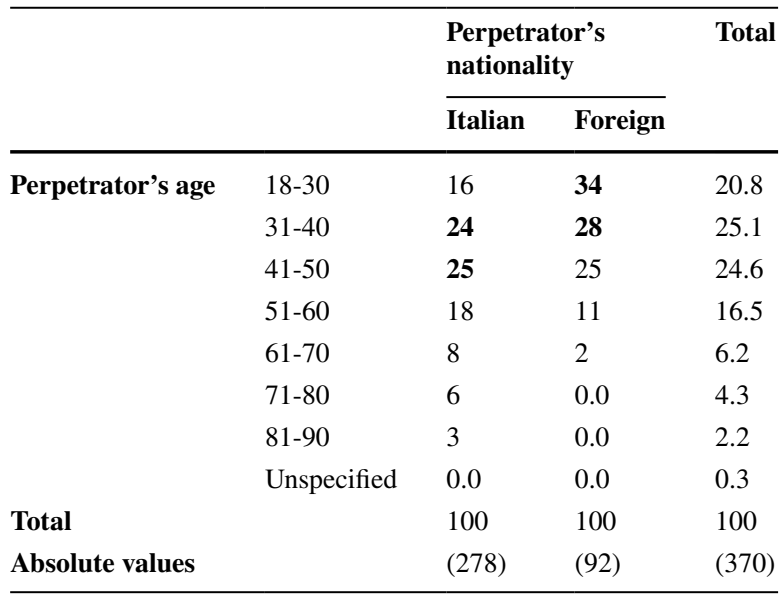

Observing the data from the opposite point of view, and comparing the nationality of the victim with that of the perpetrator, our scenario becomes more complex. It appears that, after Asian women, African women are those who are killed most often by a man from their own country (in $64 \%$ of the cases), while only $5 \%$ of Italian women were killed by Africans. Italians, instead, killed: $\mathbf{8 9 \%}$ of Italian women, roughly $44 \%$ of Eastern European women, $43 \%$ of South American women and $36 \%$ of African women (Table 5).

The following table shows that, even though these murders are committed most often by men with the same nationality, foreign women are more frequently victims by Italians than Italian women are by foreigners: Italian women are victims by foreigners in $\mathbf{1 1 \%}$ of the cases, while foreign women are victims of Italians in 39\% of the cases. (Simplifying things, our sentences seem to indicate that in Italy, Italian men are more dangerous to foreign women than foreign men are to Italian women). ${ }^{20}$ (Table 6)

Another aspect of our research concerns the outlook shown by the Italian legal system towards the perpetrator. We attempted to compare data on the perpetrator's nationality with the sentences given in first instance trials and upon appeal. Observing this table, it appears that the sentences given to foreigners in first instance trials are more severe than those given to Italians: 25\% of foreigners were given life sentences, compared to $\mathbf{1 8 \%}$ of Italians; $\mathbf{3 2} \%$ of foreigners were sentenced to 21 to 30 years in prison, compared to $\mathbf{2 8 \%}$ of Italians. ${ }^{21}$ Similarly, a higher percentage of

\footnotetext{
${ }^{20}$ Going a little deeper, for cases where the judgment indicates the profession of victims $(67 \%)$, it emerges that foreign women killed by Italians are predominantly prostitutes (in $42 \%$ of cases) and caregivers (badanti) (in $14 \%$ of cases).

21 Useful information about the brutality of the crime comes from the analysis of the weapons used. In case of foreign perpetrators are mainly bladed weapons (49\%), strangulation/suffocation (20\%) blunt objects (14\%); in the case of Italian perpetrators, we can find in the first three positions bladed weapons (32\% of cases), strangulation/suffocation (29\% of cases) and firearms ( $15 \%$ of cases).
} 


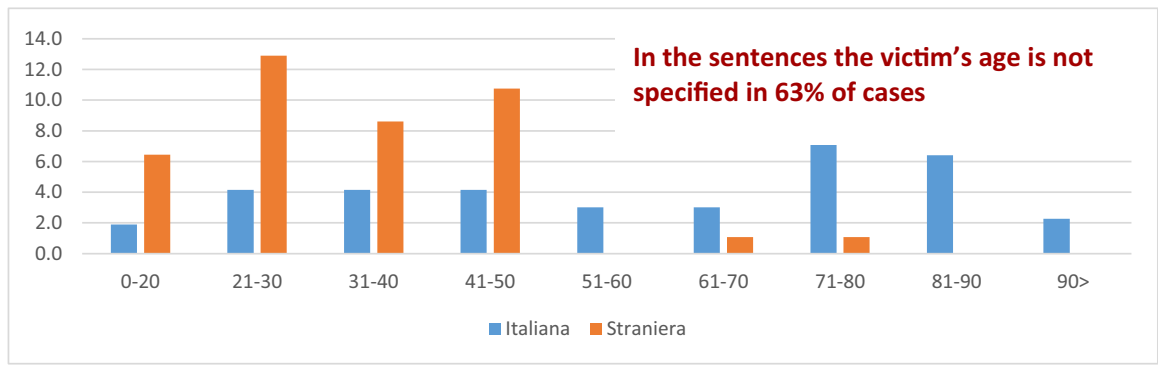

Fig. 1 Age of the victims ranked by nationality

lighter sentences were given to Italians. The same goes for sentences given upon appeal, even though the difference does become slighter, except for life sentences, which were given to $\mathbf{1 8 \%}$ of foreigners compared to $\mathbf{1 0 \%}$ of Italians (almost half) (Tables 7 and 8).

The table summarising increased or decreased sentences upon appeal confirms that foreigners receive a more severe treatment. Italians have a higher chance than foreigners of seeing their sentence reduced upon appeal $(\mathbf{3 8} \% \text {, compared to } \mathbf{3 2} \%)^{22}$. One must note that foreigners request shortened proceedings less often than Italians (67\%, compared to $73 \%$ ): this may be because they are unaware of this possibility, or are inadequately defended. We must recall that in Italy, if no other accusations were present, a shortened proceeding allowed the sentence to be reduced by one third (in the case of crimes) and a life sentence to be replaced with 30 years in prison (Tables 9 and 10). ${ }^{23}$

One final piece of data concerns the relation between the nationality of the victim and whether or not a civil action is brought into the criminal proceedings, which is interesting as regards civic awareness of this issue. One notices first of all that, above and beyond the nationality of the victim, only in $\mathbf{9 \%}$ of the cases did a public body bring a civil action into the proceeding (this is generally done by family members, in $63 \%$ of the cases). If we then observe the data concerning the victim's nationality, we note that foreign women are penalised: while for $\mathbf{3 5 \%}$ of foreign victims no one brought a civil action into the proceeding, for Italian victims, it happened in $\mathbf{2 6 \%}$ of cases (Tables 11 and 12).

\footnotetext{
22 If we wanted to identify the degree of brutality of the crime by using the aggravating factors granted in the trial, we could observe that the analysis of the sentences does not reveal a great difference between Italian perpetrators (for whom the aggravating factors are recognised in $72 \%$ of the cases) and foreign perpetrators (for whom aggravating factors are recognised in $74 \%$ of the cases).

23 We must also recall that since 2019 (law 12.4.2019 n. 33), in Italy perpetrators of crimes punished with life sentence cannot any more benefit of the shortened proceeding and the subsequent reduced sentence.
} 


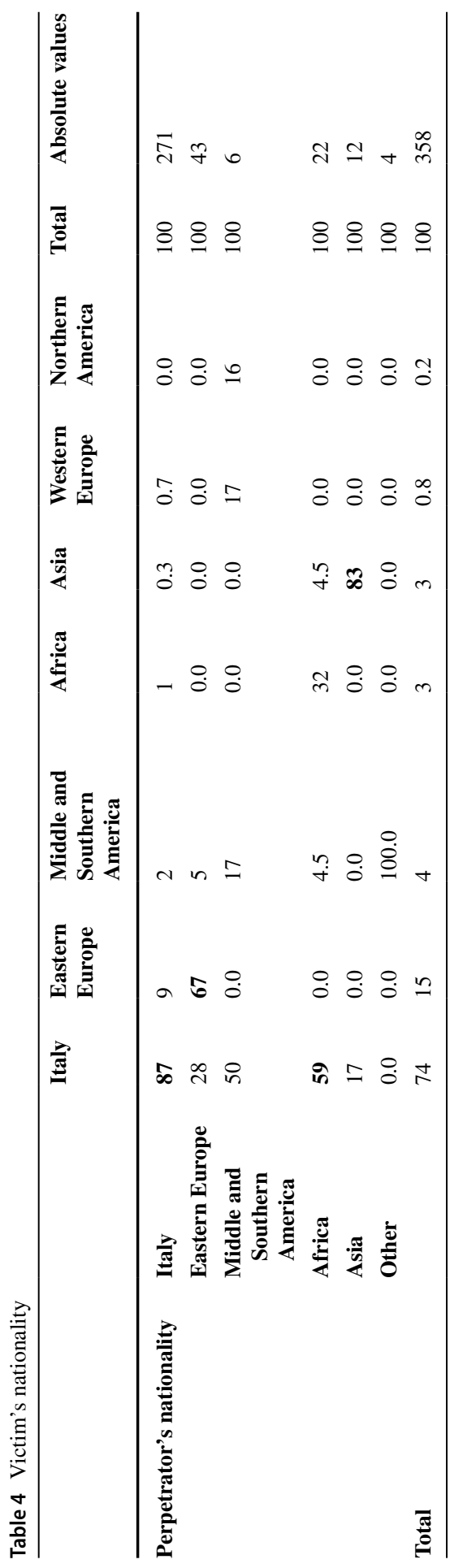




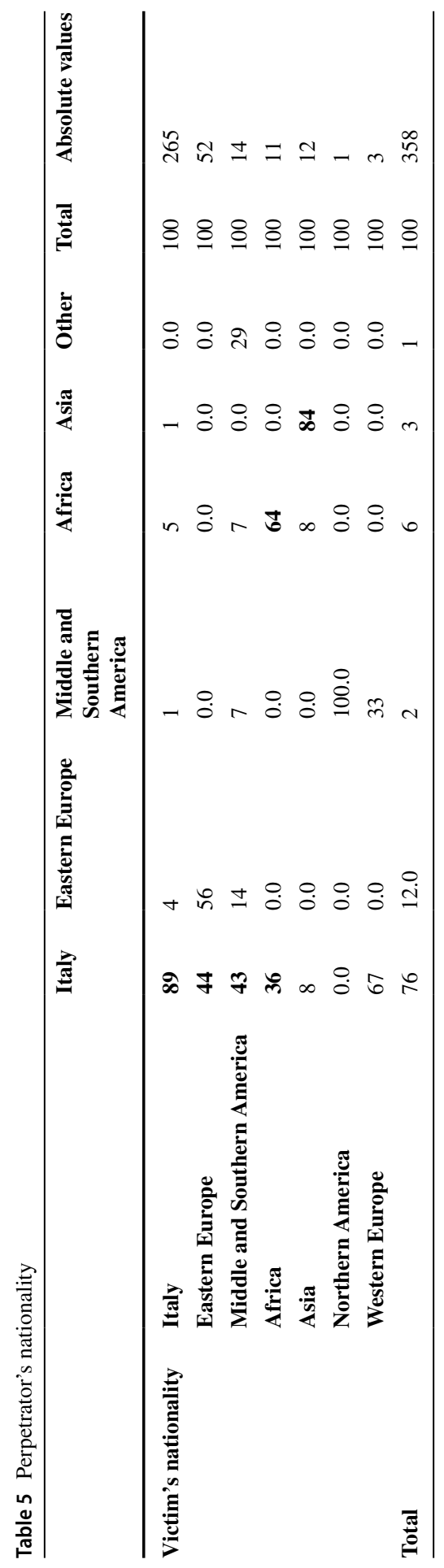


Table 6 Victim's nationality ranked by perpetrator's nationality

\begin{tabular}{llllll}
\hline & & \multicolumn{2}{l}{ Perpetrator's nationality } & Total & \multirow{2}{*}{ Absolute values } \\
\cline { 3 - 4 } & & Italian & Foreign & & \\
\hline \multirow{2}{*}{ Victim's nationality } & Italian & 89 & $\mathbf{1 1}$ & 100 & $(265)$ \\
& Foreign & $\mathbf{3 9}$ & 61 & 100 & $(93)$ \\
& Unspecified & 58 & 42 & 100 & $(12)$ \\
Total & & 75 & 25 & 100 & $(370)$ \\
\hline
\end{tabular}

Table 7 First level judgement endorsed punishment and perpetrator's nationality

\begin{tabular}{|c|c|c|c|c|}
\hline & & \multicolumn{2}{|c|}{$\begin{array}{l}\text { Perpetrator's } \\
\text { nationality }\end{array}$} & \multirow[t]{2}{*}{ Total } \\
\hline & & Italian & Foreign & \\
\hline \multirow{5}{*}{$\begin{array}{l}\text { First level judgement } \\
\text { endorsed punish- } \\
\text { ment }\end{array}$} & Absolution & 7 & 7 & 7 \\
\hline & 1-10 years & 7 & 5 & 6 \\
\hline & $11-20$ years & 40 & 31 & 35.5 \\
\hline & 21-30 years & 28 & 32 & 30 \\
\hline & Life sentence & 18 & 25 & 21,5 \\
\hline \multicolumn{2}{|l|}{ Total } & 100 & 100 & 100 \\
\hline \multicolumn{2}{|l|}{ Absolute values } & $(275)$ & $(92)$ & $(367)$ \\
\hline
\end{tabular}

Table 8 Second level judgement endorsed punishment and perpetrator's nationality

\begin{tabular}{|c|c|c|c|c|}
\hline & & \multicolumn{2}{|c|}{$\begin{array}{l}\text { Perpetrator's } \\
\text { nationality }\end{array}$} & \multirow[t]{2}{*}{ Total } \\
\hline & & Italian & Foreign & \\
\hline \multirow{5}{*}{$\begin{array}{l}\text { Second level judge- } \\
\text { ment endorsed } \\
\text { punishment }\end{array}$} & $\mathbf{0}$ & 5 & 3 & 4 \\
\hline & 0-10 years & 12 & 9 & 10.5 \\
\hline & $11-20$ & 47 & 40 & 43,5 \\
\hline & 21-30 & 26 & 30 & 28 \\
\hline & Life sentence & 10 & 18 & 14 \\
\hline Total & & 100 & 100 & 100 \\
\hline Absolute values & & $(205)$ & (63) & (268) \\
\hline
\end{tabular}

\section{A glance at the sentences}

As I mentioned at the beginning, one of our objectives was to explore the ways of reasoning, frameworks of meaning and argumentative features found in juridical discourse on femicide, by more closely analysing narrations of violence against women in a selection of judges' motivations accompanying their sentences (Bruner 2002; Di Donato 2008). Given the complexity of the subject, more work must be done to refine our tools, criteria for selection and analysis procedures. The text of a 
Table 9 Sentence outcome, procedure and perpetrator's nationality

\begin{tabular}{lllll}
\hline & & \multicolumn{2}{l}{ Perpetrator's nationality } & Total \\
\cline { 3 - 4 } & & Italian & Foreign \\
\hline Appelate Court outcome & Increased punishment & 5 & 5 & 5 \\
& Confirmed punishment & 57 & 63 & 60 \\
& Decreased punishment & $\mathbf{3 8}$ & $\mathbf{3 2}$ & 35 \\
Total & & 100,0 & 100,0 & 100,0 \\
Absolute values & & $(199)$ & $(63)$ & $(262)$ \\
\hline
\end{tabular}

Table 10 Expedited trial and perpetrator's nationality

Table 11 Civil actions

Table 12 Civil actions and victim's nationality

\begin{tabular}{lllll}
\hline & & \multicolumn{2}{l}{$\begin{array}{l}\text { Peretrator's nation- } \\
\text { ality }\end{array}$} & \\
\cline { 3 - 4 } & & Total \\
\cline { 3 - 4 } Expedited trial & Expedited trial & $\mathbf{7 3}$ & $\mathbf{6 7}$ & 70 \\
& Ordinary trial & 27 & 33 & 30 \\
Total & & 100 & 100 & 100 \\
Absolute values & & $(278)$ & $(92)$ & $(370)$ \\
\hline
\end{tabular}

\begin{tabular}{lll}
\hline & Absolute values & Percentage \\
\hline Family members only & 225 & 63 \\
$\begin{array}{l}\text { Public companies, associa- } \\
\text { tions, family members }\end{array}$ & 33 & $\mathbf{9}$ \\
Nobody & 102 & \\
Total & 360 & 28 \\
\hline
\end{tabular}

\begin{tabular}{llll}
\hline & \multicolumn{2}{l}{ Victim's nationality } & \multirow{2}{*}{ Total } \\
\cline { 2 - 3 } & Italian & Foreign & \\
\hline Nobody & $\mathbf{2 6}$ & $\mathbf{3 5}$ & 30.5 \\
$\begin{array}{l}\text { Family members only } \\
\text { Public companies, associa- }\end{array}$ & 64 & 56 & 60 \\
$\quad 10$ & 9 & 9.5 \\
$\begin{array}{l}\text { Totaons, family members } \\
\text { Absolute values }\end{array}$ & 100 & 100 & 100 \\
\hline
\end{tabular}

motivation does not allow a single narrator/speaker to be isolated; the forms of narration differ according to who is speaking (Giglioli, Cavicchioli and Fele 1997; Dino 2015; Latour 2002; Spence 1982). 
This often leads to contaminations, making the verdicts contain hybrid rationales and different modes of expression, in their legal language and their outlook (De Mauro 1963; Ginzburg 2001; Mortara Garavelli 2001). While these delicate problems will have to be dealt with at a future point in time, we have attempted to read, as an exploration, a few sentences in which the victim is a foreigner. Putting the image of the female victim at the centre of the analysis, our objective was to test whether the fact that a foreign woman was killed by a foreigner or an Italian had any effect on the reasoning used by the judge while narrating the event and reaching the verdict. From an initial reading of these cases, one has the impression that the narration is different. Frames of domination and asymmetrical structure in terms of power relations seem to come into play when a foreign woman is killed by a man of the same nationality, and this does not happen when a foreign woman is killed by an Italian. In this case, judges tend to set the event within private frames, involving sentiments and relations. As an example of this, we have chosen two cases: one in which the victim and the murderer are both foreigners, and one in which the murderer is Italian and the victim is a foreigner. ${ }^{24}$ These two sentences frame the crime in different ways: rooted in domination factors and aspects (in the first case, in which both perpetrator and victim were foreigners), or relegated to the private and sentimental sphere (if an Italian man kills a foreign woman). ${ }^{25}$

Case 1 - Perpetrator: Pakistani, 51 years old. Victim: Pakistani, daughter of the killer, 20 years old: killed with 28 stab wounds, the corpse was buried in a hole dug in the family's garden. The murderer was sentenced to 30 years in prison (with a shortened proceeding).

In the motivation, one reads that the perpetrator, acting with the moral and material complicity of his two sons-in-law and his brother-in-law, killed his daughter by cutting her throat in order to «punish the woman» for «having resolved to live outside the context of her original Pakistani family and traditions». According to the judge:

«his daughter's punishment was planned and carried out because she refused to conform with the behavioural orthodoxy demanded by her father and thus refused to change her conduct, which included living outside her original family and traditional context, not wearing traditional clothes, refusing an arranged marriage, having found an evening job that brought her into contact with people [...], having cultivated relations and a lifestyle not held to be appropriate, despite the fact that she was of age and had lived outside her family for some time». The judge continues: «this motive is none other than the manifestation of a conception of the relation between father and daughter as one of possession-domination, with a will to reaffirm his power, which had been questioned,

\footnotetext{
24 The choice of only these two cases of femicide to be analysed reflects those Cardano has appropriately defined flesh-and-blood ideal types: «individual people and not just abstract configurations of the attributes which analysis of the empirical documentation characterises as relevant» (Cardano 2010, 255).

25 The interpretation of the crime in a frame that highlights the sentimental dimension is even more interesting considering the fact that - in the case examined - the victim is a prostitute, as most of the foreign victims of Italian assassins (see note 20 ).
} 
with a punishment (eliminating his daughter) that would eliminate the problem at the root and also had the advantage of setting an example for the other members of the family». The victim «was perceived as a serious problem, not only for the consequences within the family [...]: above all, she represented an external problem, concerning the Pakistani community. Essentially, he claimed the right to determine the fate of his daughter as though she was an object». ${ }^{26}$

Case 2 - Perpetrator: Italian, 53 years old. Victim: Rumanian, 32 years old, prostitute. Killed with 23 stab wounds to her breast, pubic area and abdomen. Sentenced to 16 years in prison for murder and 2 years for improper disposal of a body (shortened proceeding).

In the motivation, one reads that the perpetrator:

«desperate on account of his wife's decision to separate, exasperated after seeing her on New Year's eve with another man, decided to search for the victim, a prostitute with whom he was acquainted [...], who, as he himself said, was a young woman he liked and who, moreover, was kind and with whom he was able to talk freely. He searched for her in the location where she worked as a prostitute, asked her to get into his truck and drove off with her [...]. He was clearheaded and entirely conscious of his actions. [...] His murderous rage then exploded. Apparently, without a motive. [...] This apparent lack of a motive immediately raises doubts as to whether he is fit to plead, based on his comprehension and above all free will. [...] It is therefore entirely legitimate and plausible to assume that the woman made an uncomplimentary remark towards the accused, [...] and thus more or less consciously and deliberately offended him, already exasperated as he was by the existential situation he was facing at the time [...]. His actions were not due to temporary mental incapacity [...] but an emotional state of passion (and therefore a psychological, not a psychopathological, condition) [...], an exacerbated condition of his soul that, unfortunately for the injured party, took root in a generally aggressive and impulsive personality». ${ }^{27}$

Widening our scenario to include the other results from our research, we notice how the same variability in the judges' narrations (emerged from the comparison between Italians and foreigners) is encountered in the variation of motives for femicide: sentimental, economic, sexual violence, altruistic, instrumental etc.

When the motive is sentimental, murderers are often portrayed as men who act upon feelings of jealousy and tormented passion, who suddenly lose control in an extreme act of domination over the body and the life of the woman they say they love.

While examining the case of a 65 year-old Italian man responsible for the murder of his cohabitant, the judges wrote: «whenever jealousy or an increasing sense of frustration - due to the perceived imbalance in the intensity of the feelings towards

\footnotetext{
${ }^{26}$ Court of First Instance of Brescia, sentence n. 1192/2007.

27 Court of Assizes of Appeal of Ferrara, sentence n. 353/2013.
} 
the victim - is identified as the motive for the crime, it cannot be deemed futile». «In the collective conscience, jealousy [...] is not perceived at all as a disproportioned motive for murder as to preclude, on a logical level, the link to the crime in terms of cause/consequence». ${ }^{28}$ The man was sentenced to 15 years in jail.

On the other hand, when the crime is committed for economic reasons and the murder is a foreigner or the woman is murdered in a context of organised crime, the narration of the magistrate is less mild and the extreme gesture does not inspire the kind of understanding that the common feeling would have experienced if the crime had not been rooted in materialistic reasons, but in a feeling, such as jealousy, common and usual enough in the dynamics between women and men.

An Italian man aged 54 gets a life sentence for the killing of an Italian prostitute who was also his cohabitant and he was exploiting her for money. Taking advantage of the fragile condition of the woman for economic reasons is deemed a vile motive, which makes the deed even more despicable: "Since the murder was clearly not inspired by reasons of passion, which can arise some kind of human understanding, as sometimes can happen for the simultaneity of the victim's provocative or unfair behaviours, but was the result of conflicts rapidly intensified due to illicit demands coming from the murderer». ${ }^{29}$

\section{The opinions of a few interviewees}

Lastly, we would like to analyse the opinions of a few interviewees on the difficulties they encountered while dealing with cases of foreign women who have been victims of violence. These difficulties arise both during the phases of prevention and initial contact, and during the judicial treatment of this violence.

The following statement was made by the female director of the Minors and Sexual Offences section of the Palermo Flying Squad, when asked how many foreign women who are victims of violence turn to the police: «Very few foreign women come to us... They only do so when they have already been stabbed», «only some women from the younger generation - who were born in Italy or who arrived when they were very young - press charges».

A female psychologist who directs a shelter for abused women, managed by the Palermo Asp, noted that the lengthiness of trials is particularly detrimental to migrant women, and that they may become a form of "torture" when the judges are not competent and sensitive.

This is how she describes a trial for people trafficking: «since the court-appointed lawyer did not encourage her to bring a civil action into the criminal proceedings, [the woman, a foreigner and suffering a high degree of psychological pain, because

\footnotetext{
${ }_{28}$ Court of Assizes of Appeal of Milan, sentence n. 24/2014.

29 Court of Assizes of Appeal of L'Aquila, sentence n. 6/2014. With regard to the severity of the sentences, it does not seem relevant that the President of the Judicial Panel is a man or a woman. Bearing in mind that in $73 \%$ of our sentences the President of the Judicial Panel is a man, in the four cases examined here, the first and the third have a woman as President, the second and the fourth have a man.
} 
she came from a country in Eastern Europe where she had been neglected, abandoned as a small child and raped by a group of subjects because as a girl she lived on the street] was not considered a victim in the trial, but only heard as a witness. She was tortured in the courtroom, and torture is the proper term, [...] the defence lawyer began asking her humiliating questions and trying, in every way, to make her seem consenting».

The psychologist continued by stating that: «we see many 'trials by media' [...] in which all possible means are used: spotlights, photos, interviews in newspapers, giving them an incredible amount of attention. [...]. But if you are an outcast, an unfortunate young foreign woman, doubly fragile, no one cares a bit, you are nobody, no one takes action».

Similar difficulties have been emphasised in the case of trials whose victims are foreign women. Here, as stated by a female magistrate belonging to the group dedicated to "Vulnerable people" at the Palermo public prosecutor's office: «extremely difficult inquiries are begun, but then these people close themselves off and are swallowed up once again by their original ethnic group. [...] This means that often a trial does not even take place, unlike cases involving Italian women, for whom trial may be held and their retractions come during the hearing».

\section{To conclude}

While waiting to carry out more in-depth work, we might say that our study confirms the peculiarity of judicial narration in the case of migrant and foreign women or those (Italian or otherwise) killed by foreigners. The "discourse" produced inside the "juridical field" proves to be a rich source in getting to know a phenomenon that still lacks structural data. Furthermore, our research highlights prejudices and distortions founded on issues involving security, fuelled by both a collective fear of the "foreigner" and a common need for reassurance (dal Lago 1999; Sayad 1999).

Some data in particular have attracted our attention by indicating research directions and interesting reflections, highlighting the complexity, the richness but also the prejudices surrounding the "legal field": the sentences given to foreigners in first instance trials are more severe than those given to Italians. The same goes for sentences given upon appeal, even though the difference does become slighter, except for life sentences, which were given to $18 \%$ of foreigners compared to $10 \%$ of Italians (almost half). Increased or decreased sentences upon appeal also confirms that foreigners receive a more severe treatment.

Observing the phenomenon on the side of the victims, we noticed that only in $9 \%$ of the cases did a public body bring a civil action into the proceeding. If we then observe the data concerning the victim's nationality, we note that foreign women are penalised: while for $35 \%$ of foreign victims no one brought a civil action into the proceeding, for Italian victims, it happened in $26 \%$ of cases.

A key feature in the judges' narrations is the topic of motive, which in the case of foreign women leaves space to contaminated arguments where different anchorings overlap, intertwining with the common feeling and using languages coming from diverse disciplinary areas (Canzio 2001; Ferrer Beltrán 2004, 
2007). Next to the technical knowledge of the judiciary area we find the echo of other scientific knowledge: from forensic pathology to psychiatry (Taruffo 2009; Tuzet 2013). The anchoring to the socio-political sphere is present as well, through the recollection of power dimensions and gender inequality. A relevant place is reserved to the sphere of sentiment and emotion, supported by a rhetorical argumentation, emphatic expressions and vivid adjectives. A mixed and not neatly outlined picture or just undetermined appear to be the outlines of femicide, devoid of certain backings in the penal law (Walton 2002).

The juridical discourse mirrors the contradictions of this picture (Falconieri 2011), making visible borderline areas and trespassed spaces of a penal law that embodies the role of "stabilisation of normative common expectations" (Prina in Ghezzi et al. 2017).

In the juridical discourse of extreme violence against women appear the borders of social space where the "symbolic battle" happens and the performative power of words is expressed in the transformation of power and authority issues into forms of accusation and responsibility. Through contamination among social representations, in the narrations of the characters of this "fight for definition" emerge the anchorings in which find an explanation and a "justification" gender violence, the institutionalised mechanisms of control and the asymmetries in the relationships between men and women (Farci, Righetti 2019; Goffman 1977; Shepherd 2012).

These initial results bear out the fact that violence against women can be fought with laws, social policies and economic interventions that eliminate inequality and offer support. Overcoming inequality, however, also requires a massive cultural revolution that renegotiates the relations between genders. Only within new symbolic spaces, indeed, can one recognise power relations and attempt to construct spaces that are free from violence.

Acknowledgments Thanks to Doctors Gioacchino Natoli and Fabio Bartolomeo for kindly making available important research material, as well as to all the people interviewed for providing us with their precious time and acute competence. A special thanks goes to all the components of the research group for their valuable advice and their ever significant dialectical comparison.

\section{Declarations}

Conflict of Interest/Competing Interest statement This essay is the outcome of a project funded by Prin (Program of Relevant National Interest) 2015, Project Title: Social representations of violence against women: the case of femicide in Italy.

This study was funded by Ministero Italiano della Università e della ricerca scientifica (Prin-2015 Programma di Rilevante Interesse Nazionale). None of the university researchers has been paid and the funds have been used only for research purposes (interviews, travel, conferences, publications, etc.).

The author declares she has no financial interests. The author has no relevant financial or non-financial interests to disclose. The author has no competing interests to declare that are relevant to the content of this article. The author certifies that she has no affiliations with or involvement in any organization or entity with any financial interest or non-financial interest in the subject matter or materials discussed in this manuscript. The author has no financial or proprietary interests in any material discussed in this article.

Open Access This article is licensed under a Creative Commons Attribution 4.0 International License, which permits use, sharing, adaptation, distribution and reproduction in any medium or format, as long as 
you give appropriate credit to the original author(s) and the source, provide a link to the Creative Commons licence, and indicate if changes were made. The images or other third party material in this article are included in the article's Creative Commons licence, unless indicated otherwise in a credit line to the material. If material is not included in the article's Creative Commons licence and your intended use is not permitted by statutory regulation or exceeds the permitted use, you will need to obtain permission directly from the copyright holder. To view a copy of this licence, visit http://creativecommons.org/licen ses/by/4.0/.

\section{References}

Agliastro, M. (2014). La violenza sulle donne nel prisma della violazione dei diritti umani e della protezione del testimone vulnerabile. Aracne.

Agodi, M. C., Consoli, M. T., Pennisi, C., \& Scuderi, M. (Eds.). (2001). Il diritto delle burocrazie. Giuffrè.

Anastasia, S., Anselmi, M., \& Falcinelli, D. (2015). Populismo penale: una prospettiva italiana. Wolkers Kluver-Cedam.

Anderson, B., \& O’Connell, D. J. (2003). Is trafficking in human beings demand driven? IOM.

Arendt, H. (1970). On Violence. Harcourt Brace \& Company.

Arfini, E., Ghigi, R., \& Magaraggia, S. (2019). Can feminism be right? Rassegna Italiana di Sociologia, $L X, 4,693-719$.

Balloni, A., Mosconi, G., \& Prina, F. (Eds.). (2004). Cultura giuridica e attori della giustizia penale. Franco Angeli.

Baratta, A. (1982). Criminologia critica e critica del diritto penale. Bologna: il Mulino.

Bartolomeo, F. (Ed.). (2017). Inchiesta con analisi statistica sul femminicidio in Italia. Ministero di Giustizia.

Bassano, G. (2017). Dentro la sentenza. E/C. Rivista on-line dell'Associazione Studi Semiotici, 1-25, (www.ec-aiss.it).

Battarino, G. (2013). Note sull'attuazione in ambito penale e processuale penale della Convenzione di Istanbul. Diritto Penale Contemporaneo, 1-16.

Bellucci, P. (2005). A onor del vero. Fondamenti di linguistica giudiziaria. UTET.

Bernardini, M. G., \& Giolo, O. (2017). Le teorie critiche del diritto. Pacini Editore.

Bourdieu, P. (1998). La domination masculine. Édition du Seuil.

Bourdieu, P. (1994). Raisons pratiques. Édition du Seuil.

Bourdieu, P. (1986). La force du droit. Actes de la Recherche en Sciences Sociales, 64(1), 3-19.

Blumer H. (1969). Symbolic Interactionism: Perspective and Method. Englewood Cliffs (N.J.): Prentice Hall.

Bruner, J. S. (2002). La fabbrica delle storie. Laterza.

Bullock, C. F. (2007). Framing Domestic Violence Fatalities. Women's Studies in Communication, 30(1), 34-63.

Canzio, G. (2001). La valutazione della prova scientifica fra verità processuale e ragionevole dubbio. Archivio Penale, 3, 61-74.

Cardano, M. (2010). Mental distress: Strategies of sense making. Health, 14(3), 253-271.

Cardano, M. (2011). La ricerca qualitativa. Bologna: il Mulino.

Casa delle donne per non subire violenza di Bologna (2017) (ed). I femicidi in Italia. Bologna: Regione Emilia Romagna.

Casadei, T. (Ed.). (2016). Donne, diritto, diritti. Giappichelli.

Casanova, C. (2016). Per forza o per amore. Salerno Editore.

Cavender, G., Bond-Maupin, L., \& Jurik, N. C. (1999). The construction of gender in reality crime Tv. Gender \& Society, 13(5), 643-663.

Cavina, M. (2011). Nozze di sangue. Laterza.

Chesnais, J. (1981). Histoire de la violence, en Occident de 1800 à nos jours. Robert Laffont.

Commissione parlamentare di inchiesta sul femminicidio, nonché su ogni forma di violenza di genere (2017). Audizione del Presidente dell'ISTAT Giorgio Alleva. Roma, seduta n. 23 del 27.09.2017.

Corradi, C. (2016). Sociologia della violenza. Mimesis. 
Corradi, C., \& Stöckl, H. (2014). Intimate partner homicide in 10 European countries. European Journal of Criminology, 11(5), 601-618.

Corradi, C., Marcuello-Servós, B. S., \& Weil, S. (2016). Theories of femicide and their significance for social research. Current Sociology, 64(7), 975-995.

Corradi, C., \& Piacenti, F. (2016). Analyzing femicide in Italy. Romanian Journal of Sociological Studies, 1, 3-17.

Creswell, J. W. (2014). Research Design: Qualitative, Quantitative, and Mixed Methods Approaches. Sage.

Dal Lago, A. (1999). Nonpersone. Feltrinelli.

Dawson, M. (2016). Punishing femicide: Criminal justice responses to the killing of women over four decades. Current Sociology, 64(7), 996-1016.

De Mauro, T. (1963). La lingua della legislazione italiana. in Id., Storia linguistica dell'Italia Unita. (pp. 424-435). Bari: Laterza.

Di Donato, F. (2008). La costruzione giudiziaria del fatto. Franco Angeli.

Di Nicola, P. (2018). La mia parola contro la sua. HarperCollins.

Dino, A. (2012). Un mondo in frantumi, Narcomafie, XX, 45-53.

Dino, A. (2015). Tra ambiguità e malinteso: schermaglie di "una battaglia per l'identità" in una conversazione tra mafiosi. Polis, XXIX (1), 33-58.

Dino, A. (2021). Femminicidi a processo. Mimesis.

Direzione Centrale Anticrimine (2018) (ED.). ... questo Non è Amore. Polizia Moderna, 1-16.

Dubé, R. (2012). La fonction du droit criminel moderne: de la protection de la société à la stabilisation des expectatives normatives. Droit et Société, 82(3), 659-688.

Dugan, L., Nagin, D. S., \& Rosenfeld, R. (2003). Exposure Reduction or Retaliation? The Effects of Domestic Violence Resources on Intimate-Partner Homicide. Law \& Society, 37(1), 169-198.

Eures (2019a). Violenza di genere e femminicidio in Italia. Rapporto Eures 2019. (www.eures.it).

Eures (2019b). Caratteristiche, dinamiche e profili di rischio dell'omicidio in famiglia in Italia. (www. eures.it).

Falconieri, S. (2011). La legge della razza. Bologna: il Mulino.

Farci, M. \& Righetti, N. (2019). Italian men's rights activism and online backlash against feminism. Rassegna Italiana di Sociologia, LX (4), 765-781.

Farr, R., \& Moscovici, R. (1984). Social Representations. Cambridge University Press.

Feci, S., \& Schettini, F. (Eds.). (2017). La violenza contro le donne nella storia. Viella.

Ferrajoli, L. (1993). La differenza sessuale e le garanzie dell'uguaglianza. Democrazia e diritto, 33 (2), 49-73.

Ferrajoli, L. (2015). Il principio di uguaglianza e la differenza di genere. giudicedonna.it, 3, 1-14.

Ferrari, V. (2006). Diritto e società. Laterza.

Ferrarotti, F. (1979). Alle radici della violenza. Rizzoli.

Ferrer Beltrán, J. (2004). Prova e verità nel diritto. Bologna: il Mulino.

Ferrer Beltrán, J. (2007) La valoración racional de la prueba. Madrid, Barcelona, Buenos Aires: Marcial Pons.

Fiandaca, G. (2005). Il giudice di fronte alle controversie tecnico-scientifiche. Diritto \& Questioni pubbliche, 5, 8-23.

Fiandaca G. (2020), Note su punizione, riparazione e scienza penalistica. Sistema Penale, 1-20.

Fineman, M. A. (2008). The vulnerable subject. Yale Journal of Law and Feminism, 20(1), 1-23.

Foucault, M. (1977). Microfisica del potere. P. Pasquino \& A. Fontana (Eds). Torino: Einaudi.

Foucault, M. (1994). Poteri e strategie. P. Dalla Vigna (Ed). Milano: Mimesis.

Ghezzi, M.L., Mosconi, G., Pennisi, C., Prina F. \& Raiteri M. (Eds) (2017). Processo penale, cultura giuridica e ricerca empirica. Santarcangelo di Romagna $(\mathrm{RN})$ : Maggioli.

Ghigi, R. \& Sassatelli, R. (2018). Corpo, genere e società. Bologna: il Mulino.

Ghigi, R. \& Rottenberg, C. (2019). Feminisms in neoliberal times. From neoconservative agendas to global protests. Rassegna Italiana di Sociologia, LX (4), 655-666.

Giglioli, P.P, Cavicchioli S. \& Fele, G. (1997). Rituali di degradazione. Bologna: il Mulino.

Ginzburg, C. (2001). Rapporti di forza. Storia, retorica e prova. Feltrinelli.

Giolo, O. (2015). Oltre la critica. Appunti per una contemporanea teoria femminista del diritto. Diritto $e$ Questioni Pubbliche, 15(2), 62-81.

Giolo, O., \& Pastore, B. (Eds.). (2018). Vulnerabilità. Carocci.

Giomi, E. (2015). Tag femminicidio. Problemi dell'informazione, XL, 3, 549-574. 
Giomi, E. \& Magaraggia, S. (2017). Relazioni brutali. Genere e violenza nella cultura mediale. Bologna: il Mulino.

Gius, C., \& Lalli, P. (2014). "I loved her so much, but I killed her", ESSACHESS. Journal for Communication Studies, 7(2), 53-75.

Gobo, G. (2015). The Next Challenge: From Mixed to Merged Methods. Qualitative Research in Organizations and Management, 10(4), 329-331.

Goffman, E. (1977). The Arrangement between the Sexes. Theory and Society, 4(3), 301-331.

Gregoratto, F. (2017). Why Love Kills: Power, Gender Dichotomy, and Romantic Femicide. Hypatia, $32(1), 135-151$.

Grzyb, M. A. (2016). An explanation of honour-related killings of women in Europe through Bourdieu's concept of symbolic violence and masculine domination. Current Sociology, 64(7), 1036-1053.

Gusfield, J. R. (1968). On Legislating Morals: The Symbolic Process of Designating Violence. California Law Review, 56(1), 54-73.

Héritier, F. (1996). De la violence. Odile Jacob.

Iezzi, D. F. (2010). Intimate femicide in Italy. In F. Palumbo, C. Natale Lauro, \& M. Greenacre (Eds.), Data Abalysis and Classfication (pp. 85-91). Springer Verlag.

Istat (2007). La violenza e i maltrattamenti contro le donne dentro e fuori la famiglia. Anno 2006. (www. istat.it).

Istat (2015). La violenza contro le donne dentro e fuori la famiglia. Anno 2014. (www.istat.it).

Istat (2018). Le molestie e i ricatti sessuali sul lavoro. Anni 2015-2016. (www.istat.it).

Jackson, B. S. (1985). Semiotics and Legal Theory. Routledge \& Kegan Paul.

Jackson, B. S. (1998). Truth or proof? The criminal verdict. International Journal for the Semiotics of Law, XI, 33, 227-274.

Jacquemet, M. (1996). Credibility in Court. Cambridge University Press.

Karadole, C. (2012). Femicidio: la forma più estrema di violenza contro le donne. Rivista di Criminologia, Vittimologia e Sicurezza, VI, 1, 16-38.

Lamb, S., \& Keon, S. (1995). Blaming the Perpetrator. Psychology of Women Quarterly, 19, 209-220.

Lalli, P. (Ed.) (2020). L'amore non uccide. Bologna: il Mulino.

Landowski, E. (1988). Verité et véridiction en droit. Droit et Societé, 8, 47-63.

Latour, B. (2002). La fabrique du droit, une ethnographie du Conseil d'État. La Découverte.

MacKinnon, C. A. (2006). Are Women Human? Harvard University Press.

Matoesian, G. M. (2001). Law and the Language of Identity. Oxford University Press.

Merli, A. (2015). Violenza di genere e femminicidio. Diritto Penale Contemporaneo, 1, 1-59.

Mortara Garavelli, B. (2001). Le parole e la giustizia. Einaudi.

Pateman, C. (1988). The Patriarcal Welfare State. Princeton University Press.

Pavich, G. (2013). Le novità del decreto legge sulla violenza di genere. Diritto Penale Contemporaneo, 1-22.

Pazè, E. (2013). Diseguali per legge. Franco Angeli.

Pennisi, C. (1991). La costruzione sociologica del fenomeno giuridico. Giuffrè.

Pennisi, C. (1998). Istituzioni e cultura giuridica. Giappichelli.

Pezzini, B. (Ed.). (2012). Genere e diritto. Bergamo University Press.

Pitch, T. (1998). Un diritto per due. Il Saggiatore.

Pitch, T. (2008). Qualche riflessione attorno alla violenza maschile contro le donne. Studi sulla questione criminale, 3(2), 7-13.

Pocar, V., \& Ronfani, P. (2008). La famiglia e il diritto. Laterza.

Popitz, H. (1986) Phänomene der Macht. Tübingen: J.B.C. Mohr (Paul Siebeck).

Radford, J., \& Russell, D. (1992). Femicide: The Politics of Woman Killing. Twayne Publishers.

Raiteri, M. (1990). Il giudice selettore. Giuffrè.

Re, L., E. Rigo \& Virgilio M. (2019). Le violenze maschili contro le donne. Studi sulla questione criminale, XIV (2), 9-33.

Recchione, S. (2013). Il decreto sul contrasto alla violenza di genere. Diritto Penale Contemporaneo, 1-21. Sayad, A. (1999). La double absebce. Édition du Seuil.

Scarponi, S. (Ed.). (2014). Diritto e genere. Cedam.

Shepherd, L. J. (2012). Gender, Violence and Popular Culture. Routlegde.

Simone, A., \& Boiano, I. (Eds.). (2018). Femminismo ed esperienza giuridica. Efesto.

Sofsky, W. (1996). Traktat über die Gewalt. Fischer Verlag.

Spence, D. P. (1982). Narrative Truth and Historical Truth. W. W. Norton \& Co.. 
Spinelli, B. (2008). Femminicidio. Dalla denuncia sociale al riconoscimento giuridico internazionale. Franco Angeli.

Taruffo, M. (2009). La semplice verità. Il giudice e la costruzione dei fatti. Laterza.

Tringali, M. C. (2019). Femminicidio e violenza di genere. SEB.

Tuzet, G. (2013). Filosofia della prova giuridica. Giappichelli.

Viola, F. (1995). The judicial Truth. Persona y Derecho, 32, 249-266.

Virgilio, M. (2010). Violenza maschile sulle donne e strumentario giuridico. Genesis, IX, 115-134.

Walton, D. (2002). Legal Argumentation and Evidence. Pennsylvania University Press.

Weil, S. (2017). The Advantages of Qualitative research into Femicide. Qualitative Sociology Review, XIII, 3, 118-124.

Publisher's note Springer Nature remains neutral with regard to jurisdictional claims in published maps and institutional affiliations.

Alessandra Dino is Full Professor of Sociology of Deviance at the University of Palermo, Italy. She is a member of the Scientific Committee of "Historia Magistra", "Narcomafie", "Liberi Editori". As a scholar of mafia phenomena, she has applied the ethnographic method to the analysis of symbolic processes and to the study of internal changes in Sicilian Mafia. She has studied the identity forms and the features of female roles in mafia criminal organisations, analysing their changes in time. She has deepened the understanding of the connections between mafia and religion, looking for historical roots and a symbolic dimension, using historical references, judicial documents and interviews to support her arguments. In her most recent researches, she has reserved specific attention to the international network of mafia, and to the leadership systems in Sicilian mafia, studying the relationship among Cosa Nostra, the business world and the politics, delving into the connection between mafia organised crime and transnational economic crime. Her most recent publications include: Novas Tendencias da criminalidade transnacional (with W. Fanganiello Maierovitch) (2010); Der Mezzogiorno und die Organisierte Kriminalität (2010); La mafia devota $\left(2010^{2}\right)$, Gli ultimi padrini (2011); Organisierte Kriminalität (2012). Women and transnational organized crime (2012); Frauen in italienischen Mafia (2013); Au royaume des discours incomplets. Ambigüité et malentendu dans la conversation entre mafieux (2013), Affari e complicità mafiose tra Palermo e Punta Raisi (2014), Mafia, politica e democrazia: il potere e le stragi in Italia (2015 ), A colloquio con Gaspare Spatuzza (2016); 19. "These Dead Are Not Ours”: Identity Factors, Communicative Aspects and Regulative Meanings of Violence inside Cosa Nostra (2019); Waiting for a new leader: Eras and transitions in Cosa Nostra (2019); Violenza di Genere e femminicidio nelle narrazioni giudiziarie in Italia (2019); Femminicidi a processo. Dati, stereotipi e narrazioni della violenza di genere (2021). 